\title{
THE IMPLEMENTATION OF PEER AND SELF-ASSESSMENT IN PRACTICAL GROUP WORK FOR STUDENTS
}

\author{
Nurul Azizah Ria Kusrini, M.Pd \\ Institut Pesantren KH. Abdul Chalim Mojokerto \\ nurulazizah@ikhac.ac.id
}

\begin{abstract}
Group work which takes students as a central study pattern is great help for English learners. Nowadays many English teachers select this kind teaching and learning method in the classroom. But actually, the group study simultaneously presents many problems which seriously influence learning when it is carrying out in the classroom. However theories and previous researches suggest that peer and self-assessment can makes students have a clear learning target, discipline themselves and therefore generate better learning results. So in this study the researcher try to research peer and self-assessment that was put into practical group study in the classroom. This study answer the following question: what extent of peer and self-assessment prevents the problems occurring in group work?, thus this study aims to find the effective of peer and self-assessment in encouraging students' attention in practical group working. This study used qualitative descriptive approach. Data was collected through observing, interviewing and analyzing of the implementation of it in the classroom. The finding is peer and self-assessment could effectively prevent the problems occurring and promoted the group study efficiency greatly.
\end{abstract}

Key term- Group work, peer and self-assessment, feedback.

\section{RELATED LITERATURE (THEORITICAL BACKGROUND)}

In language teaching and learning, two kinds of ability of the use of Language are involved. "One kind is the ability to select which form of sentences is appropriate for a particular linguistic context. The second is the ability to recognize which function is fulfilled by a sentence in a particular communicative situation"(Widdowson, 1978:6). Group work is a good way to make students know how to put English language in a communicative use. In term of speaking a research by Lynne Flowerdew (in Harmer, 2007:166) found that "it was especially appropriate in Hongkong, where it used accorded with the Confucian principles which her Cantonese-speaking students were comfortable with. Furthermore, her students were prepared to evaluate each other's performance both positively and negatively in a bigger group a natural tendency for self-effacement made this less likely". In other hand, group work can increase the frequency and efficiency of interaction and expression. It is conducive to develop the student to express her/his own expression and has more and better opportunities in increasing problem-solving 
capabilities. As Harmer (2007) stated that it promotes learner autonomy by allowing students to make their own decisions in the group without being told what to do by the teacher.

A research from Oakland University told us that compared to students taught traditionally, students taught in a manner that incorporate in small-group learning achieve higher grades, learn at a deep level, retain information longer(Oakley, 2004). Group work provides a communicative environment in which students ultimately have to use the language, productively and receptively, in unrehearsed contexts (Brown, 1980). Group work does provide every team member full opportunities to give play their capability and establish good relations of cooperation. But at the same time group study existed many problems which seriously affect students' learning effect and outcome.

The problems are as following: in group study, some students are not centralized when they are in the discussion. They often get off the subject, discussing some contents which have nothing to do with the subject. Some students remove themselves outside the group study by themselves, or do something else. Some of them do not listen attentively when their classmates are making presentation, as if it has nothing to do with his or her. In addition, students ignore the chances of learning from each other in group discussion or group presentation. Moreover, individual student's performance and the development are neglected easily by the teacher who is more directed his or her attention on group progress in the process of group learning. Obviously, all of the above problems hinder the smooth development and efficiency of group learning and individual student learning outcome.

To overcome this problem, it is necessary to put peer and self-assessment in group learning in the classroom. Brown (2001)has shown a number of advantages of self and peer-assessment: speed, direct involvement of students, the encouragement of autonomy, and increased motivation because of self-involvement in the process of learning.

Peer assessment is an assessment of students by other students, both formative reviews to provide feedback and summative grading (Bostock, 2009). It means that feedback is one important point in the process to stimulate students' attention attentively in order that group work will give play their capability as participants to fulfill a communicative learning. Peer assessment can encourage students to give feedback to each other. Such peer review has an extremely positive effect on group work. It encourages students to monitor each other and, as a result, helps them to become better at selfmonitoring. Muncie (in Harmer, 2007) suggests a further advantage, namely that whereas students see teacher comment as coming from an expert, as a result of which they feel 
obliged to do what is suggested, even when we are only making suggestion, they are much more likely to be provoked into thinking about what they are writing if the feedback comes from one of their peers. Thus when responding to work during the drafting stage, peer feedback is potentially extremely beneficial. However, in order to make sure that the comment is focused, we might want to design a form such as the one suggested by Victoria Chan (in Harmer, 2007) where students are given sentences to complete such as $I$ like that part..., I'm not sure about..., The specific language errors I have noticed are..., etc.

Previous research concluded students can become better language learners when they engage in deliberate thought about what they are learning and how they are learning it as a reflection. In this kind of reflection, students step back from the learning process to think about their language learning strategies and their progress as language learners. Such self-assessment encourages students to become independent learners and can increase their motivation. Allowing students to assess the performance of other group members may therefore provide a more justifiable means of assessment. In a research report from Ying (2006) showed that partner evaluation methods in teaching spoken English has a certain validity. Most students hold a supportive attitude of positive evaluation methods and partner evaluation and teacher evaluation scores are very close. An action experiment research by Tetcher (2010) proved that students' involvement in developing evaluation criteria and peer assessment promote their studies. She suggested peer assessment should be introduced into the courses and allowed students to participate in the making assessment standards in order to benefit student learning and future employment.

Therefore, it is believed that in peer assessment, students have the opportunity to observe the whole process of learning of their peers, and often the details they observed are more than that of teachers. Peer assessment also promotes autonomous learning, reflective learning and less dependence on the teacher. It helps students to become more autonomous learners, better able to recognize the strengths and weaknesses of their own work; it enables assessment to become part of the learning process rather than an adjunct to it; Involving students in the assessment process. Furthermore, learn a great deal from each other, and with large student numbers, the importance of student feedback increases as the availability of tutor feedback decreases. Setting up and facilitating student peerassessment can provide students with deep learning experiences as well as a wealth of feedback to evaluate. In other words, this assessment method can stir up interest in 
learning, learning motivation and sense of responsibility, to establish a friendly and active begin.

From the above statements, it could be seen that peer and self-assessment plays an essential part in our teaching and students' learning process. So, the implementation of it will be observed and analyzed in this study in order to know the extent of peer and selfassessment prevents the problem encouraging in practical group work.

\section{II.ASSESSMENT RUBRICS DESIGNING}

How to assess student oral English ability is an important aspect of concern. If criteria is too strict and too demanding, it easily leads to students a sense of tension and anxiety and students real standard can't be assessed efficiently; if standard is too low, even without request, it will become a mess and greatly reduce the efficiency of the assessment, all of which will affect the improvement of students learning outcome. In order to mobilize learning enthusiasm of students which is the basic purpose, to improve learner participation, to minimize anxiety, to low self-esteem of students and to strengthen classroom learning process control, the criteria is the key point in assessments. The assessment rubric for students' practical group learning was made basing Bloom's taxonomy, which helps us determine teaching and assessment of goals. His cognitive objectives in the field include six main categories: knowledge; comprehend; use; analysis; synthesis; evaluation (Nitko, 2007).

From low to high, the goals not only emphasizes the knowledge but also more importantly emphasize the cultivation of student's intelligence and reflects the cumulative nature of knowledge and level of classification, namely high-level teaching goal is to be achieved through a low-level goals. Bloom's taxonomy is the student behavior is from simple to complex according to the order of arrangement and, therefore, educational objectives are of continuity and cumulative. He focuses on the evaluation of the learning process and looks evaluation as part of the learning process. He advocates teaching should be more use of alternative evaluation methods-formative evaluation. As our students were graduates, they had high cognitive ability, the ability of controlling and the ability of analysis and criticism. Therefore, our main purpose was to assess students' high order thinking--the ability of solving problems by using English and the communication ability in making oral presentation in a real context.

When making particular educational decisions, effective peer evaluation needs a reasonable evaluation principles, they are: Be clear about the learning targets you want to 
assess; Be sure that the assessment techniques you select match each learning target; Be sure that the selected assessment techniques serve the needs of the learners; Be sure to use multiple indicators of achievement for each learning target; Be sure that when you interpret the result of assessment you take their limitation into account (Nitko, 2007).

Based on the above principles, the peer assessment rubric was made. In order to let students understand and acknowledge the purpose, the importance and the usefulness of the peer and self-assessment, the expectations of them as members participating in group work and how they should contribute towards group work. During the process of making the rubric, students were asked to be involved in the particular assessment decision. Firstly, assessment criteria was presented to students and asked them to give suggestions. Students put forward reasonable some suggestions to the criteria. Then the teacher moderated it according to students' suggestions. Finally evaluation criterion was produced with the involvement of students' work. In order to be clear, let see the tables I and II below:

\section{Table I}

\section{Rating Scales}

Group: Student No:

Numerical: e.g. rate each criteria out of ten.

Graphics:

Do the students work well with others?

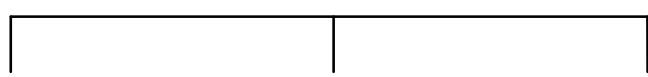

Never occasionally always

Descriptive graphic: as above but with description

E.g. Always works well, shares materials, listen to others opinions, contributes to discussion, and etc.

(Hamilton, 2010) 


\section{Table II}

Peer Assessment Rubric

Group:

\begin{tabular}{|c|c|c|c|c|}
\hline & Articulation & Coherence & $\begin{array}{c}\text { Flexibility and } \\
\text { Relevance }\end{array}$ & $\begin{array}{l}\text { Total } \\
\text { Score }\end{array}$ \\
\hline $100-85$ & $\begin{array}{l}\text { Plenty vocabularies, } \\
\text { correct grammar, } \\
\text { good pronunciation }\end{array}$ & $\begin{array}{l}\text { a long and coherent } \\
\text { speaking, occasional pause } \\
\text { when speaking }\end{array}$ & $\begin{array}{l}\text { Natural and active } \\
\text { participation in talking, } \\
\text { use proper words }\end{array}$ & \\
\hline $84-75$ & $\begin{array}{l}\text { Plenty vocabularies. } \\
\text { There're mistakes in } \\
\text { grammar and } \\
\text { pronunciation, but doesn't } \\
\text { affect communication. }\end{array}$ & $\begin{array}{l}\text { Short and simple speaking, } \\
\text { long time pause, complete } \\
\text { the communication } \\
\text { basically }\end{array}$ & $\begin{array}{l}\text { Active participation, } \\
\text { sometimes not keep the } \\
\text { point, properly use } \\
\text { words basically }\end{array}$ & \\
\hline $74-60$ & $\begin{array}{l}\text { Less vocabularies, } \\
\text { mistakes in grammar } \\
\text { and pronunciation, } \\
\text { affect } \\
\text { communication }\end{array}$ & $\begin{array}{l}\text { Short and simple speaking, } \\
\text { longer time pause, complete } \\
\text { communication basically. }\end{array}$ & $\begin{array}{l}\text { participate in the } \\
\text { discussion, } \\
\text { sometimes unable to } \\
\text { suitable for new topic }\end{array}$ & \\
\hline $59-0$ & $\begin{array}{l}\text { Much less words, more } \\
\text { mistakes in grammar and } \\
\text { pronunciation so that } \\
\text { block communication }\end{array}$ & $\begin{array}{l}\text { Very short and simple } \\
\text { speaking, no coherence, } \\
\text { almost no communication }\end{array}$ & $\begin{array}{l}\text { Almost unable to join } \\
\text { in the } \\
\text { discussion, }\end{array}$ & \\
\hline
\end{tabular}

(Hamilton, 2010)

In brief, the joint of discussion of assessment rubrics not only have students to get a clear understanding of the assessment of the implementation of standards, operating methods, but also enhance the communication and interaction between teachers and students and promote effective learning and teaching.

\section{III.METHODOLOGY}

In this study the researcher used qualitative descriptive approach where the researcher itself takes a role as main instrument. The data was collected through observation and interview of teacher and students activities in the classroom. The assessment activity was held twice. The twice assessments activity was anonymous. 33 students involved in the group and assessment work was divided into 8 groups--4-5 students as a group.

For the first time, the assessment was taken within the scale of each group. Each group was given two hours to design and discuss a project of group presentation. The rubric was distributed to each student. See appendix I. After group work, students rated the 
contribution of each group members and gave comments. The teachers talked with students who were rated low and gave comments in the whole class. The comments were mainly praising and encouraging. Then the peer rating results were feedback to each student.

The second time of assessment was held within the scale of the whole class. Each group did a 20-minute presentation with a further 3 minutes for questioning. Each presentation centered around the topic with group members' previous discussion. After each group presentation, student audience had 5 minutes to rate the performance of each group and gave comments, and then to the next round. Each student rated 3 group's performance. The specific requirements were provided to students ahead of two weeks in order to enable students to understand the learning targets and have better learning results.

The rubric handout was explained in detail in the case of students made unfair scoring due to ambiguous about the meaning of the rubrics. After all groups' presentation and peer assessment were completed, the evaluation of the results of each group was returned to each group being evaluated to let them get a more comprehensive and evaluation results. Then a face-to-face talk between the teacher and each group members was given and the feedback from the teacher's was provided at the same time. Finally, each student carried out a written self-assessment to enhance a better and complete learning task motivation.

After talking with each group students, the teachers' feedback was given to each group both as encouragement and as an instruction for their improvement of future learning. Then each student was asked to make a self-assessment; rating him/herself and write down their reflections of their performance in the group activities such as advantages, disadvantages and future improvement strategies, and then handed them to the teacher. In their own writing-down assessment, every student made an objective judgment for himself. Some of them said they like this kind of learning style and hoped other similar English course, such as writing, listening and reading, should adopt it too.

In term of validity and reliability, whether the assessment is valid or not, it depends on "how the results are interpreted and used"(Nitko, 2007:38). Validity was ensured basically in peer and self-assessment implemented in this practical group work. Because this assessment was implemented based on the requirement of curriculum and was carried out in a real communicative context. Students' ability of solving problems was fully assessed in a real communicative context in which students fully embodied their ability to using English of solving problems and the ability of cooperation etc. The basic purpose of 
the evaluation was achieved. Another embodiment of validity of peer and self-assessment was it provided a good guide. It inspired the enthusiasm of students learning and very helpful for teachers to design next teaching program. Of course, one time's assessment couldn't determine the actual English proficiency of students.

In the future the same assessment should be implemented in classroom teaching at least three times. If the assessment results are consistent, it will be more valid. Reliability is not the assessment instrument itself, it refers to "the consistency of an assessment results if and when they are repeated" (Nitko, 2007:57). This assessment has its reliability because of the evaluation rubric was uniform for all the students who were involved in the assessment. They were from the same profession, the range of their English proficiency differences was the same, and each group assessors was random chosen. All of these avoided the bias in the process of assessment and ensure the results consistent.

\section{FINDING AND ANALYSIS DATA}

By implementation of peer and self- assessment in group work students, evaluators and students who were evaluated were all involved in the evaluation process felt the benefits of peer and self-assessment. Peer and self-assessment also enhanced the sense of students' responsibility and initiative. Students views of peer and self-assessment clearly showed that a peer rating did stimulate greater participation and responsibility, establish a clear assessment structure, and improve learning skills and provide more feedback. The performance also proved that students more enthusiastically and actively participated in the group discussion than before. Rare students were found to be distracted away from the group discussion. They performed better in public speaking; they got a good listening habit; and more cooperative. It could be seen from their carefully listening and keep taking notes from the beginning to the end in order to make the assessment well-founded. Implementation peer and self-assessment allowed students both to exchange learning and experience from the performance of fellow students.

Self and peer assessment nurture students to learn how to correctly assess their own learning results and learn to be responsible for their own learning. For the evaluators, the adoption of evaluation of others provides a more in-depth look at their own work and found their own inadequacies. It is also the process of promoting evaluators themselves. In the classroom, the process of timely rating and comments made students have timely reflection of their own learning. This involves students engaging in critical self-reflection, focusing on obtaining a clearer idea of the features of effective learning and thereby 
increasing their understanding of the subject matter being studied. Besides that, students' assessment provided the teacher valuable information of having a deep understanding of each individual student learning so that the teacher could design a better teaching syllabus and made teaching and learning more targeted and rate students final grades more fair and objective. Because the assessment marks would put into final grades, all the students were extremely carefully and diligent when they were doing group work, assessment and presentation.

In interviewing of students after their assessment activity, the researcher found that they express their opinions of the assessment activity frankly. One said: "I feel it interesting and like it...", "I learned a lot from my classmates by rating them...", "It makes me excited to be rated and to rate others...". There were students spoke frankly: "In the past I usually turned a deaf ear when my classmates were doing presentation. Now I can't. I have to focus my attention on their performance...", "Because my classmates were assessing my performance, I forced myself to speak more...", a shy student said. Another student said: "By reading the comments my classmates gave me, I know I should make my pronunciation clearer and correct afterwards, otherwise the audience do not understand what I'm talking about...". Students also said: "Rating is like a mirror which allows us to see our own mistakes and know which mistakes could be avoided...", "With the evaluation task, I cannot be distracted. It trains my listening and reminds of myself: Don't make the same mistake as theirs".

In other word, peer and self-assessment is an important component of formative assessment which is often used to set the speed of learning for students to ensure that students to engage in a targeted learning task, to enhance the role of learning, to reveal where the problem lies. It not only changes the previous single interaction between teachers and students, but also greater emphasizes the interaction between peers.

\section{CONCLUSION}

As peer and self-assessment is based on student-centered, most students expressed their joy of it. It mobilizes students' enthusiasm, motivates students in their learning, multi-directionally increases their participation in classroom activities, thereby it enhances their oral communicative competence. And as learning is built on the concept of problembased learning, student cognitive awareness is raised. They are aware of where their strong points are and where their weak points are through peer and self-assessment and get to learn how to solve their learning problems. 
The implementation of peer and self-assessment makes final assessment more rational and convincing, makes teachers better understanding students' learning. Timely, clear and objective feedback provided makes teachers in peer and self-assessment ensure student effective learning and provide encouragement to enhance communication and exchange between teachers and students more powerful learning ability will be reinforced. It also shows that the positive comments from teachers can protect students' self-esteem, self-confidence so as to enhance their learning enthusiasm and initiative. Potential problems may occur when students doing assessment. For example, some students may rate unfairly because of some personal subjective reasons, but with careful attention, arrangement and implementation, the problems can be avoidable to a great length.

It has been to be conclusive that the implementation of peer and self-assessment is really a good way to prevent the problem occurring of group work activities; promote group work efficiency; and it is valuable to be popularized in group work. The researcher expects the next research will analyze the other alternative assessment of group work in the classroom. It is also expected that it will be useful for the teachers especially teachers of English in increasing students' attention in various practical group work activities.

\section{REFERENCES}

Bostock, Stephen. (2009). Student Peer Assessment; The Higher Education Academy. from http:/www.palatine.ac.uk/files/994.pdf

Brown, H. Douglas. 2001. Teaching by Principles; An interactive Approach to Language Pedagogy. New York: Person Education.

Brown, H.D. 1980. Principles of Language Learning and Teaching. New Jersey: Prentice Hall.

Hamilton, Amy. 2010. Collaborative Learning and Self \& Peer-Assessment Journal of Language Teaching and Research Vol.1No. 6.

Harmer, Jeremy. 2007. The Practice of English Language Teaching. Edinburgh: Pearson Education Limited.

Nitko, Anthony J. 2007. Educational Assessment. New Jersey.

Oakley, Barbara. 2004. Turning Student Groups into effective teams. Student Centered Learning Journal Vol.2No. 1. 
Widdowson, H. G. 1978. Teaching Language as Communication. London: Oxford University Press.

Ying, Gu. 2006. On the Effectiveness of Peer Assessment in Oral English Teaching in the Effectiveness. Yu Cheng Institute Journal Vol.2No. 1. 